\title{
SCIDoC
}

\author{
International Journal of Dentistry and Oral Science (IJDOS) \\ ISSN: 2377-8075
}

\section{Evidence Based Clinical Practice Guidelines For Management Of Acute Pain With Apical Periodontitis}

Research Article

Surendar ${ }^{*}$, Srujana Hemmanur ${ }^{2}$

${ }^{1}$ Senior Lecturer, Department of Conservative dentistry and Endodontics, Saveetha Dental College and Hospitals, Saveetha Institute of Medical and Technical Sciences, Saveetha University, Chennai-77, India.

${ }^{2}$ Post Graduate Student, Department of Conservative dentistry and Endodontics, Saveetha Dental College and Hospitals, Saveetha Institute of Medical and Technical Sciences, Saveetha University, Chennai-77, India.

\section{Abstract}

Introduction: Acute apical periodontitis (AAP) or symptomatic apical periodontitis is a common endodontic diagnosis and requires immediate attention as the patient may present with moderate to severe pain. However, an array of symptoms may be presented which may lead us to a collective diagnosis of AAP. The management protocol of AAP is not standardised throughout the world and is seen to depend on personal choice. A need to establish standardised protocol for AAP is thus imperative. Aim: This article gives an overview on the management of AAP and suggests a sequential approach for pain management in cases presenting with symptomatic apical periodontitis.

Materials and Methods: Randomised clinical trials, Systematic reviews, literature reviews and previously published clinical practice guidelines that deal with the management of acute apical periodontitis (AAP) were selected and data extracted.

Results: A protocol based on the existent information was suggested for the management of pain caused by acute apical periodontitis.

Conclusion: Pain management is an essential step for patient management and needs to be focused on as pain alleviation requires immediate attention.

Keywords: Acute; Pain; Periodontitis; Relief; Rcts.

\section{Introduction}

Clinical practice guidelines as mentioned by Field et al are "systematically developed statements to assist practitioners and patients in arriving at decisions on appropriate health care for specific clinical circumstances" [1]. Clinical practice guidelines guide us towards formulation of a consolidated protocol that is evidence based, is valid, transparent, inclusive of all the clinical scenarios given under a subheading and accessible to everyone who needs them [2]. Factors like prevalence of a disease, the burden that an illness causes, relevance to local practice patterns, amount of variation in practice patterns, cost management and availability of evidence guide in selection of topics for clinical practice guidelines [3].
Acute apical periodontitis (AAP) happens to be an inflammatory condition of the periapical tissues that usually results from irreversible pulpitis and/or pulpal necrosis. Although chemical and physical factors may result in pulpitis, majority of cases have a microbial cause, usually secondary to either dental caries or trauma [4]. AAP is an inflammatory process rather than infectious however some bacteria has been demonstrated in the periapical region [5]. Patients with AAP present with pain from mild to severe in nature. With moderate and severe pain as presentation, the management becomes an endodontic emergency [6]. Emergency management of acute apical periodontitis (AAP) accounts for $2 \%$ to $6 \%$ [7]. Pain has been one of the most common symptoms of

\section{*Corresponding Author:}

Surendar,

Senior Lecturer, Department of Conservative dentistry and Endodontics, Saveetha Dental College and Hospitals, Saveetha Institute of Medical and Technical Sciences, Saveetha University, Chennai-77, India.

Email Id: surendars.sdc@saveetha.com

Received: April 28, 202

Accepted: May 28, 2021

Published: May 30, 2021

Citation: Surendar, Srujana Hemmanur. Evidence Based Clinical Practice Guidelines For Management Of Acute Pain With Apical Periodontitis. Int J Dentistry Oral Sci. 2021;08(05):2649-2652. doi: http://dx.doi.org/10.19070/2377-8075-21000518

Copyright: Surendar 2021 . This is an open-access article distributed under the terms of the Creative Commons Attribution License, which permits unrestricted use, distribution and reproduction in any medium, provided the original author and source are credited. 
a diseased state and can be considered as a protective mechanism through which the body notifies of a harmful stimulus [8]. Pain thus becomes the most common symptom that patients present to a dentist. The patient approaching a dentist in most of the scenarios experience pain and discomfort [9].

Previously our team has a rich experience in working on various research projects across multiple disciplines [10-24]. Now the growing trend in this area motivated us to pursue this project.

Pain management is more or less based on personal choices rather than following a stringent protocol. The aim of the current study is to formulate a protocol for the management of acute pain caused by apical periodontitis in adult patients.

\section{Materials and Methods}

\section{Study Identification}

MEDLINE and EmBase, SCOPUS, Web of Science and Google scholar were thoroughly searched for articles with search words as acute pain, acute apical periodontitis, analgesics, antibiotics, surgical management, etc and their synonyms. The search was repeated for all credible interventions of pain management. Pharmacotherapeutics, non-surgical measures like endodontic management, surgical intervention, extraction, occlusal adjustment and no treatment were investigated.

\section{Study Selection}

Randomised clinical trials, Systematic reviews, literature reviews and previously published clinical practice guidelines that deal with the management of acute apical periodontitis (AAP) were selected.

\section{Clinical Presentation}

The clinical presentation of AAP appears in a wide array of symptoms. The progression of AAP from inflamed pulp is almost always inevitable, hence the diagnosis may be tricky. An incorrect diagnosis may lead to in appropriate management which takes a toll on both the patient and the dental surgeon. Patients with AAP usually present with dull, throbbing and pain that is constant; absence of swelling; a delayed positive or negative response to pulp vitality testing; absence of thermal sensitivity of the tooth; and pain on biting or percussion with often reports of slight extrusion of the tooth in the socket $[7,25,26]$. Radiographic changes such as widening of the periodontal ligament space may be pre- sent, but frank radiolucency will not be evident. Vitality tests have reportedly been affected by factors like the amount of residual pulp, number of roots and root canals, status of calcification, size and type of restoration on the tooth in question and habits [27]. Proper history taking and clinical as well as radiographic evaluation shall lead us to correct diagnosis.

\section{Treatment Options}

Amongst the various options available for management of acute pain as a result of symptomatic apical periodontitis, the ones mentioned in texts and practiced widely are pharmacotherapy, necrotic pulp extirpation with or without chemomechanical disinfection of the root canal space, intracanal medicament of various analgesics, antibiotics or corticosteroids, non surgical endodontic therapy, occlusal adjustment and no treatment per say.

Sutherland et al suggested the use of systemic NSAIDs in conjunction with non surgical endodontic therapy for the management of AAP. The use of antibiotics was not recommended as apical periodontitis is an inflammatory process. No significant benefit upon use of systemic antibiotics, intracanal treatment with combination of steroid and antibiotic and trephination through attached gingiva has been reported [7]. A clinical practice guidelines by Glenny and Simpson suggested the initiation of nonsurgical endodontic therapy (root canal) on the affected tooth as soon as possible. An appropriate dose of analgesics either preemptive or post operatively must be prescribed for pain control. Extraction should be considered in cases with poor prognosis. Relieving of occlusion in case of hyperocclusion is an alternative but the relief in pain occurs in around 12 hours [28]. However, the most cardinal treatment option is endodontic management of the affected tooth [26].

A cochrane review by Moore et al, suggested the use of OTC analgesics for management of acute pain. It is surprising that a maximum of $50 \%$ of pain relief is obtained by in take of oral analgesics alone. However, the endodontic diagnosis is not mentioned in this study [29]. Many authors have mentioned the ineffectiveness of use of systemic antibiotics in management of acute dental pain as a result of symptomatic apical periodontitis, This can be attributed to the nature of disease that does not involve microbial infection. However, apical abscesses should be managed with systemic antibiotics [30-33]. A recent RCT concluded chemomechanical disinfection and extirpation of necrotic pulp without chemomechanical disinfection as an effective method of pain alleviation in patients with symptomatic localised apical periodontitis with no mean difference in either groups [34, 35].

Figure 1. Suggested protocol for the management of pain caused by acute apical periodontitis.

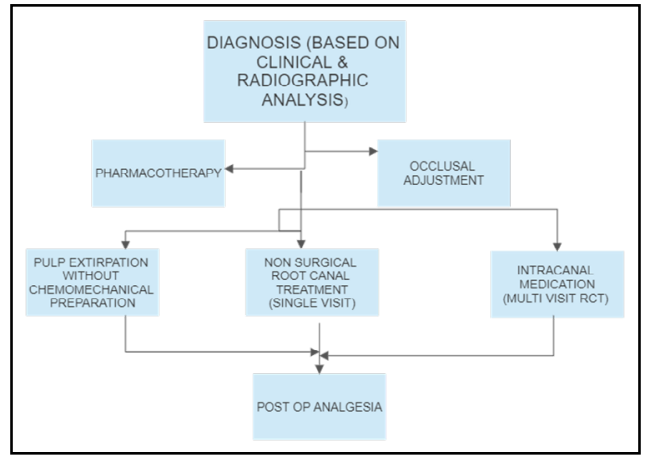


Hence, in patients where immediate canal disinfection cannot be done, pulpal extirpation must be done to relieve pain.

Amongst newer techniques for pain management in patients with symptomatic apical periodontitis is acupuncture [36]. Also, intracanal cryotherapy helps in management of pain in conjunction with chemomechanical preparation along with avoidance of postoperative systemic analgesics [37].

Our institution is passionate about high quality evidence based research and has excelled in various fields [38-48].

\section{Protocol For Management Of Acute Pain In Aap}

Endodontic diagnosis of the affected tooth must be done effectively. An endodontic management of the affected tooth must be initiated. It is advisable to prescribe a pre-emptive analgesic to ensure patient cooperation and pain control prior to and during the endodontic therapy. Occlusal adjustment must be done such that the affected tooth is relieved of occlusion. Access to all the root canals must be established and they should be adequately disinfected. In case complete disinfection cannot be achieved, the pulpal tissue must be removed so as to effectively reduce pain. A postoperative analgesia is recommended. Preferably two-visit endodontic therapy should be performed.

\section{Conclusion}

Management of pain is extremely essential. In patients with symptomatic apical periodontitis, it becomes all the more indispensable. Various options exist for management of pain of which an individual selects the plans which suits them the most. A guide to immediate pain management is a prerequisite and hence, must be emphasised on. However, more clinical trials comparing different parameters need to be performed to arrive at a solid and consistent finding.

\section{References}

[1]. Institute of Medicine (US) Committee to Advise the Public Health Service on Clinical Practice Guidelines. Clinical Practice Guidelines: Directions for a New Program. Field MJ, Lohr KN, editors. Washington (DC): National Academies Press (US); 2014.

[2]. Sutherland SE, Matthews DC, Fendrich P. Clinical practice guidelines in dentistry: Part II. By dentists, for dentists. J Can Dent Assoc. 2001 Sep;67(8):448-52. Pubmed PMID: 11583605.

[3]. Hayward RS, Laupacis A. Initiating, conducting and maintaining guidelines development programs. CMAJ. 1993 Feb 15;148(4):507-12. Pubmed PMID: 8431814.

[4]. Siqueira JF Jr. Endodontic infections: concepts, paradigms, and perspectives. Oral Surg Oral Med Oral Pathol Oral Radiol Endod. 2002 Sep;94(3):28193. Pubmed PMID: 12324780

[5]. Debelian GJ, Olsen I, Tronstad L. Anaerobic bacteremia and fungemia in patients undergoing endodontic therapy: an overview. Ann Periodontol. 1998 Jul;3(1):281-7. Pubmed PMID: 9722712.

[6]. Elsevier. 2021 Jan.

[7]. Sutherland S, Matthews DC. Emergency management of acute apical periodontitis in the permanent dentition: a systematic review of the literature. J Can Dent Assoc. 2003 Mar;69(3):160. Pubmed PMID: 12622880.

[8]. Swieboda P, Filip R, Prystupa A, Drozd M. Assessment of pain: types, mechanism and treatment. Ann Agric Environ Med. 2013;Spec no. 1:2-7. Pubmed PMID: 25000833.

[9]. Ingle JI, Glick DH. Differential diagnosis and treatment of dental pain. Endodontics. 1994;4:524-49.

[10]. Govindaraju L, Gurunathan D. Effectiveness of Chewable Tooth Brush in Children-A Prospective Clinical Study. J Clin Diagn Res. 2017
Mar;11(3):ZC31-ZC34. Pubmed PMID: 28511505.

[11]. Christabel A, Anantanarayanan P, Subash P, Soh CL, Ramanathan M, Muthusekhar MR, et al. Comparison of pterygomaxillary dysjunction with tuberosity separation in isolated Le Fort I osteotomies: a prospective, multi-centre, triple-blind, randomized controlled trial. Int J Oral Maxillofac Surg. 2016 Feb;45(2):180-5. Pubmed PMID: 26338075.

[12]. Soh CL, Narayanan V. Quality of life assessment in patients with dentofacial deformity undergoing orthognathic surgery--a systematic review. Int J Oral Maxillofac Surg. 2013 Aug;42(8):974-80. Pubmed PMID: 23702370.

[13]. Mehta M, Deeksha, Tewari D, Gupta G, Awasthi R, Singh H, et al. Oligonucleotide therapy: An emerging focus area for drug delivery in chronic inflammatory respiratory diseases. Chem Biol Interact. 2019 Aug 1;308:206215. Pubmed PMID: 31136735.

[14]. Ezhilarasan D, Apoorva VS, Ashok Vardhan N. Syzygium cumini extract induced reactive oxygen species-mediated apoptosis in human oral squamous carcinoma cells. J Oral Pathol Med. 2019 Feb;48(2):115-121. Pubmed PMID: 30451321.

[15]. Campeau PM, Kasperaviciute D, Lu JT, Burrage LC, Kim C, Hori M, et al. The genetic basis of DOORS syndrome: an exome-sequencing study. Lancet Neurol. 2014 Jan;13(1):44-58. Pubmed PMID: 24291220.

[16]. Sneha S. Knowledge and awareness regarding antibiotic prophylaxis for infective endocarditis among undergraduate dental students. Asian Journal of Pharmaceutical and Clinical Research. 2016 Oct 1:154-9.

[17]. Christabel SL, Gurunathan D. Prevalence of type of frenal attachment and morphology of frenum in children, Chennai, Tamil Nadu. World J Dent. 2015 Oct;6(4):203-7.

[18]. Kumar S, Rahman RE. Knowledge, awareness, and practices regarding biomedical waste management among undergraduate dental students. Asian Journal of Pharmaceutical and Clinical Research. 2017;10(8):341.

[19]. Sridharan G, Ramani P, Patankar S. Serum metabolomics in oral leukoplakia and oral squamous cell carcinoma. J Cancer Res Ther. 2017 JulSep;13(3):556-561. Pubmed PMID: 28862226.

[20]. Ramesh A, Varghese SS, Doraiswamy JN, Malaiappan S. Herbs as an antioxidant arsenal for periodontal diseases. J Intercult Ethnopharmacol. 2016 Jan 27;5(1):92-6. Pubmed PMID: 27069730.

[21]. Thamaraiselvan M, Elavarasu S, Thangakumaran S, Gadagi JS, Arthie T. Comparative clinical evaluation of coronally advanced flap with or without platelet rich fibrin membrane in the treatment of isolated gingival recession. J Indian Soc Periodontol. 2015 Jan-Feb;19(1):66-71. Pubmed PMID: 25810596.

[22]. Thangaraj SV, Shyamsundar V, Krishnamurthy A, Ramani P, Ganesan K, Muthuswami M, et al. Molecular Portrait of Oral Tongue Squamous Cell Carcinoma Shown by Integrative Meta-Analysis of Expression Profiles with Validations. PLoS One. 2016 Jun 9;11(6):e0156582. Pubmed PMID: 27280700.

[23]. Ponnulakshmi R, Shyamaladevi B, Vijayalakshmi P, Selvaraj J. In silico and in vivo analysis to identify the antidiabetic activity of beta sitosterol in adipose tissue of high fat diet and sucrose induced type- 2 diabetic experimental rats. Toxicol Mech Methods. 2019 May;29(4):276-290. Pubmed PMID: 30461321.

[24]. Ramakrishnan M, Bhurki M. Fluoride, Fluoridated Toothpaste Efficacy And Its Safety In Children-Review. International Journal of Pharmaceutical Research. 2018 Oct 1;10(04):109-14.

[25]. Hargreaves KM. Cohen's Pathways of the Pulp Expert Consult. 10th.

[26]. Glenny AM, Simpson T. Clinical practice guideline on emergency management of acute apical periodontitis (AAP) in adults. Evidence-based dentistry. $2004 \mathrm{Mar} ; 5(1): 7-11$.

[27]. Lin LM, Skribner J. Why teeth associated with inflammatory periapical lesions can have a vital response. Clin Prev Dent. 1990 Apr-May;12(1):3-4. Pubmed PMID: 2376105.

[28]. Emara RS, Abou El Nasr HM, El Boghdadi RM. Evaluation of postoperative pain intensity following occlusal reduction in teeth associated with symptomatic irreversible pulpitis and symptomatic apical periodontitis: a randomized clinical study. Int Endod J. 2019 Mar;52(3):288-296. Pubmed PMID: 30171777.

[29]. Moore RA, Wiffen PJ, Derry S, Maguire T, Roy YM, Tyrrell L. Non-prescription (OTC) oral analgesics for acute pain - an overview of Cochrane reviews. Cochrane Database Syst Rev. 2015 Nov 4;2015(11):CD010794. Pubmed PMID: 26544675.

[30]. Cope A, Francis N, Wood F, Mann MK, Chestnutt IG. Systemic antibiotics for symptomatic apical periodontitis and acute apical abscess in adults. Cochrane Database Syst Rev. 2014 Jun 26;(6):CD010136. Pubmed PMID: 24967571.

[31]. Lockhart PB, Tampi MP, Abt E, Aminoshariae A, Durkin MJ, Fouad AF, et al. Evidence-based clinical practice guideline on antibiotic use for the urgent management of pulpal- and periapical-related dental pain and intraoral swelling: A report from the American Dental Association. J Am Dent Assoc. 
2019 Nov;150(11):906-921.e12. pubmed PMID: 31668170.

[32]. Alghamdi F, Alharbi E, Alhusseini Z, Aljahdali E, Alkhanbshi R, Baradwan $\mathrm{O}$, et al. The Therapeutic Protocols and Endodontic Management of Acute Apical Abscess in Adults: A systematic Review. Health Sciences. 2020;9(2):8-16.

[33]. Tampi MP, Pilcher L, Urquhart O, Kennedy E, O'Brien KK, Lockhart PB, et al. Antibiotics for the urgent management of symptomatic irreversible pulpitis, symptomatic apical periodontitis, and localized acute apical abscess: Systematic review and meta-analysis-a report of the American Dental Association. J Am Dent Assoc. 2019 Dec;150(12):e179-e216. Pubmed PMID: 31761029 .

[34]. Wolf E, Dragicevic M, Fuhrmann M. Alleviation of acute dental pain from localised apical periodontitis: A prospective randomised study comparing two emergency treatment procedures. J Oral Rehabil. 2019 Feb;46(2):120126. Pubmed PMID: 30307640.

[35]. Stenberg M. Emergency treatment in teeth with symptomatic apical periodontitis-a randomized clinical study.

[36]. Arslan H, Ahmed HMA, Yıldız ED, Gündoğdu EC, Seçkin F, Arslan S. Acupuncture reduces the postoperative pain in teeth with symptomatic apical periodontitis: a preliminary randomized placebo-controlled prospective clinical trial. Quintessence Int. 2019;50(4):270-277. Pubmed PMID: 30887960

[37]. Vera J, Ochoa J, Romero M, Vazquez-Carcaño M, Ramos-Gregorio CO, Aguilar RR, et al. Intracanal Cryotherapy Reduces Postoperative Pain in Teeth with Symptomatic Apical Periodontitis: A Randomized Multicenter Clinical Trial. J Endod. 2018 Jan;44(1):4-8. Pubmed PMID: 29079057.

[38]. Vijayashree Priyadharsini J. In silico validation of the non-antibiotic drugs acetaminophen and ibuprofen as antibacterial agents against red complex pathogens. J Periodontol. 2019 Dec;90(12):1441-1448. Pubmed PMID: 31257588.

[39]. J PC, Marimuthu T, C K, Devadoss P, Kumar SM. Prevalence and measurement of anterior loop of the mandibular canal using CBCT: A cross sectional study. Clin Implant Dent Relat Res. 2018 Aug;20(4):531-534. Pubmed PMID: 29624863

[40]. Ramesh A, Varghese S, Jayakumar ND, Malaiappan S. Comparative estima- tion of sulfiredoxin levels between chronic periodontitis and healthy patients - A case-control study. J Periodontol. 2018 Oct;89(10):1241-1248. Pubmed PMID: 30044495.

[41]. Ramadurai N, Gurunathan D, Samuel AV, Subramanian E, Rodrigues SJL. Effectiveness of $2 \%$ Articaine as an anesthetic agent in children: randomized controlled trial. Clin Oral Investig. 2019 Sep;23(9):3543-3550. Pubmed PMID: 30552590.

[42]. Sridharan G, Ramani P, Patankar S, Vijayaraghavan R. Evaluation of salivary metabolomics in oral leukoplakia and oral squamous cell carcinoma. J Oral Pathol Med. 2019 Apr;48(4):299-306. Pubmed PMID: 30714209.

[43]. Ezhilarasan D, Apoorva VS, Ashok Vardhan N. Syzygium cumini extract induced reactive oxygen species-mediated apoptosis in human oral squamous carcinoma cells. J Oral Pathol Med. 2019 Feb;48(2):115-121. Pubmed PMID: 30451321.

[44]. Mathew MG, Samuel SR, Soni AJ, Roopa KB. Evaluation of adhesion of Streptococcus mutans, plaque accumulation on zirconia and stainless steel crowns, and surrounding gingival inflammation in primary molars: randomized controlled trial. Clin Oral Investig. 2020 Sep;24(9):3275-3280. Pubmed PMID: 31955271.

[45]. Samuel SR. Can 5-year-olds sensibly self-report the impact of developmental enamel defects on their quality of life? Int J Paediatr Dent. 2021 Mar;31(2):285-286. Pubmed PMID: 32416620.

[46]. R H, Ramani P, Ramanathan A, R JM, S G, Ramasubramanian A, et al. CYP2 C9 polymorphism among patients with oral squamous cell carcinoma and its role in altering the metabolism of benzo[a]pyrene. Oral Surg Oral Med Oral Pathol Oral Radiol. 2020 Sep;130(3):306-312. Pubmed PMID: 32773350 .

[47]. Chandrasekar R, Chandrasekhar S, Sundari KKS, Ravi P. Development and validation of a formula for objective assessment of cervical vertebral bone age. Prog Orthod. 2020 Oct 12;21(1):38. Pubmed PMID: 33043408.

[48]. Vijayashree Priyadharsini J, Smiline Girija AS, Paramasivam A. In silico analysis of virulence genes in an emerging dental pathogen A. baumannii and related species. Arch Oral Biol. 2018 Oct;94:93-98. Pubmed PMID: 30015217. 